\title{
LABORATORY HYDRAULIC FRACTURING TESTS OF ROCK SAMPLES WITH WATER, CARBON DIOXIDE, AND SLICKWATER
}

\section{S. STANISŁAWEK ${ }^{1}$, P. KĘDZIERSKI ${ }^{2}$, D. MIEDZIŃSKA ${ }^{3}$}

\begin{abstract}
Hydraulic fracturing of rocks boosts the production rate by increasing the fracture-face surface area through the use of a pressurized liquid. Complex stress distribution and magnitude are the main factors that hinder the use of information gathered from in situ hydraulic fracturing in other locations. Laboratory tests are a good method for precisely determining the characteristics of these processes. One of the most important parameters is breakdown pressure, defined as the wellbore pressure necessary to induce a hydraulic fracture. Therefore, the main purpose of this investigation is to verify fracture resistance of rock samples fractured with the assistance of the most popular industry fluids. The experiments were carried out using a stand designed specifically for laboratory hydraulic fracturing. Repeatable results with a relative error within the range of $6-11 \%$ prove that the experimental methodology was correct. Moreover, the obtained results show that fracturing pressure depends significantly on fluid type. In the case of a water test, the fracturing pressure was $7.1 \pm 0.4 \mathrm{MPa}$. A similar result was achieved for slickwater, $7.5 \pm 0.7 \mathrm{MPa}$; however, a much lower value $(4.7 \pm 0.5 \mathrm{MPa})$ was registered in the case of carbon dioxide.
\end{abstract}

Keywords: fracturing test stand, hydraulic fracturing, tensile rock strength

\footnotetext{
${ }^{1}$ PhD., Eng., Warsaw Military University, Faculty of Mechanical Engineering, Kaliskiego 2, 00-908 Warsaw, Poland, e-mail: sebastian.stanislawek@wat.edu.pl

${ }^{2} \mathrm{PhD}$., Eng., Warsaw Military University, Faculty of Mechanical Engineering, Kaliskiego 2, 00-908 Warsaw, Poland, e-mail: piotr.kedzierski@wat.edu.pl

${ }^{3} \mathrm{PhD}$., Eng., Warsaw Military University, Faculty of Mechanical Engineering, Kaliskiego 2, 00-908 Warsaw, Poland, e-mail: danuta.miedzinska@wat.edu.pl
} 


\section{INTRODUCTION}

Hydraulic fracturing is the fracturing of rock with a pressurized liquid to increase the fracture-face surface area and boost production rate [1]. Complex stress distribution and magnitude are the main factors that hinder the use of information gathered from in situ hydraulic fracturing (HF) in other locations [2]. The huge scale of a typical experiment and the fact that most of the equipment is buried are additional problems. As a result, details about the exact conditions of the tests are usually unknown. Laboratory tests are not commonplace for the same reasons, but they are a reasonable method for precisely determining process characteristics [3,4]. One of the most important parameters is breakdown pressure, $\mathrm{P}_{\mathrm{c}}$, defined as the wellbore pressure necessary to induce a hydraulic fracture. This influences both the design of the pressure installation and the seismic activity in an area. In known literature, HF criteria are usually based on theories for characteristics of impermeable rocks $[5,6]$ :

$$
\mathrm{P}_{\mathrm{c}}-\mathrm{P}_{\mathrm{o}}=\mathrm{T}_{\mathrm{hf}}-3 \sigma_{\mathrm{h}}-\sigma_{\mathrm{H}}-2 \mathrm{P}_{\mathrm{o}}
$$

where:

$\sigma_{\mathrm{h}}, \sigma_{\mathrm{H}}-$ the minimum and maximum horizontal principal stresses, $\mathrm{P}_{\mathrm{o}}-$ initial pore pressure in a rock formation, $\mathrm{T}_{\mathrm{hf}}-$ hydraulic fracturing tensile strength

These equations do not include the influence of the type of hydraulic fluid or its hydrodynamic state, and therefore it is difficult to predict the value of $\mathrm{P}_{\mathrm{c}}$ when a given composition of liquids is utilized. Water is the most popular fracturing fluid and often includes additives that reduce fluid friction in tubing and surfactants that provide low surface tension. Carbon dioxide and nitrogen are pumped into especially tight reservoirs as, in a gaseous state, they are easily removed and do not block flow. Not many studies have examined the impact of fluid type on fracture extension, and so the main purpose of this investigation is to verify fracture strength of rock samples fractured with the most popular industry fluids.

\section{EXPERIMENTAL SETUP AND PROCEDURE}

A specialized stand designed for laboratory fracturing, described in detail in [7] (Fig.1), was used for laboratory testing. It is composed of low- and high-pressure circuits. The low-pressure circuit is responsible for a specimen's hydrostatic compression, which represents in situ stress. The high- 
pressure circuit is designed for pressurizing a given fracturing fluid. Initially, a sample made of shale rock was used; however, due to its low strength it was difficult to mount without damaging its surface. Therefore, based on other scientists' approaches [8], another rock material was used instead of shale. Test samples were formed from a marble specimen without any visible fractures. In each test, they were placed in the vessel and pressed hydrostatically with an outer pressure equal to 4.0MPa. Unfortunately, this value is much lower than the one usually used onsite; however, using higher pressure would induce higher values in the high-pressure circuit. Previous experiments have shown that there is a risk of improper sealing between rock and injector that could dramatically distort results. All specimens had an inner diameter of $25 \mathrm{~mm}$, an outer diameter of $96 \mathrm{~mm}$, and a height of $85 \mathrm{~mm}$. They were derived from a single block of rock and were cut parallel to the observable anisotropy plane. Obviously, this could influence the results; however, the main purpose of this paper was to examine the behaviour of fluids, not the properties of the marble material. Fracturing was achieved by a gradual increase of pressure in the high-pressure circuit. Each experiment lasted around one minute, thereby guaranteeing a relatively stable temperature, especially in the low-pressure circuit. Three fracturing fluids were tested: water, carbon dioxide, and slickwater (water with added FR (1\%), Biocide (3\%), and Clay Control 1\%). Slickwater composition was defined based on [8]. A pressure increase in the low-pressure circuit was an indicator of effective damage to the specimen, as it meant that the fracturing fluid had migrated rapidly through the marble material. During all tests the pressure was recorded over time using a data acquisition module.

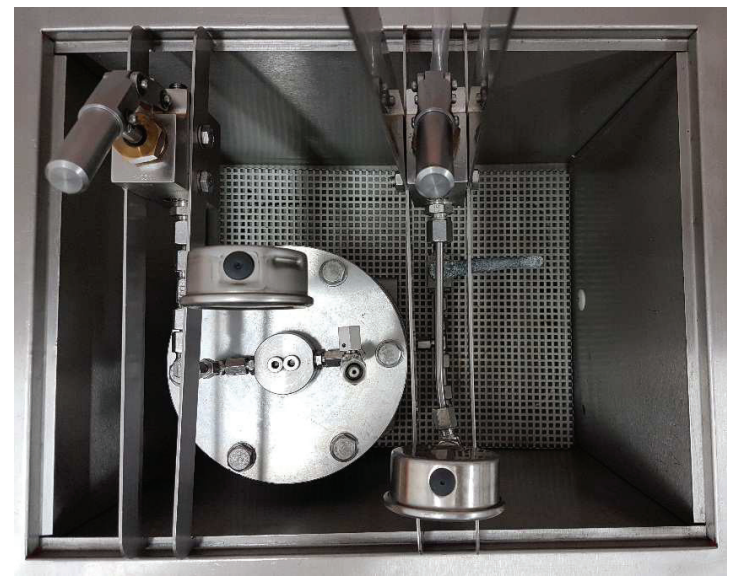

Fig. 1. Test stand 


\section{RESULTS}

The results of the experimental tests are presented in Fig. 2 and Table 1. Standard deviation was calculated based on the equation:

$$
s=\sqrt{\frac{1}{n-1} \sum_{i=1}^{n}\left(x_{i}-\bar{x}\right)^{2}}
$$

where:

$n$ - number of data points, $x_{i}$ - individual data values, $\bar{x}$-mean of $x_{i}$

Due to the limited number of tests, determination of statistical uncertainty required additional calculations.

Based on t-distribution, the confidence interval may be defined as:

$$
\bar{x}-\frac{t_{0.95}}{\sqrt{n}} s<m<\bar{x}+\frac{t_{0.95}}{\sqrt{n}} s
$$

where:

$t_{0.95}-\mathrm{t}$-score of $\mathrm{t}$-distribution (for four tests it is 2,1318 )

\begin{tabular}{|c|c|c|c|c|c|}
\hline Test number & Fracturing fluid & $\begin{array}{c}\text { Fracturing } \\
\text { pressure }[\mathrm{MPa}]\end{array}$ & Average $[\mathrm{MPa}]$ & $\begin{array}{c}\text { Standard } \\
\text { deviation }(\mathrm{s})\end{array}$ & $\begin{array}{c}\text { Confidence } \\
\text { Interval }\end{array}$ \\
\hline Test 1 & \multirow{4}{*}{ Water } & 6.6 & \multirow{4}{*}{7.1} & \multirow{4}{*}{0.37} & \multirow{4}{*}{0.8} \\
\hline Test 2 & & 7.0 & & & \\
\hline Test 3 & & 7.1 & & & \\
\hline Test 4 & & 7.5 & & & \\
\hline Test 5 & \multirow{4}{*}{$\mathrm{CO} 2$} & 4.0 & \multirow{4}{*}{4.7} & \multirow{4}{*}{0.5} & \multirow{4}{*}{1} \\
\hline Test 6 & & 4.7 & & & \\
\hline Test 7 & & 5.0 & & & \\
\hline Test 8 & & 5.1 & & & \\
\hline Test 9 & \multirow{4}{*}{ Slickwater } & 6.6 & \multirow{4}{*}{7.5} & \multirow{4}{*}{0.63} & \multirow{4}{*}{1.4} \\
\hline Test 10 & & 7.9 & & & \\
\hline Test 11 & & 8.0 & & & \\
\hline Test 12 & & 7.6 & & & \\
\hline
\end{tabular}

Table 1. Experimental results 


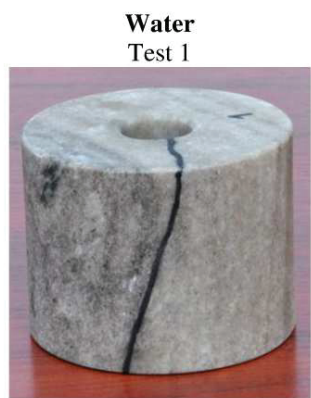

Test 2

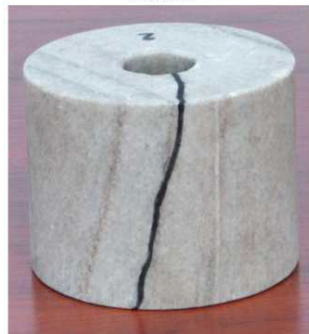

Test 3

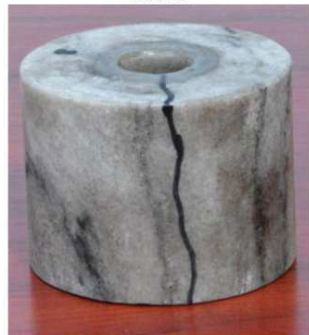

Test 4

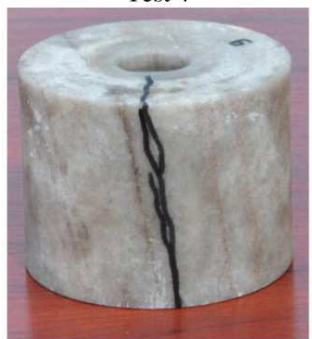

$\mathrm{CO2}$

Test 5

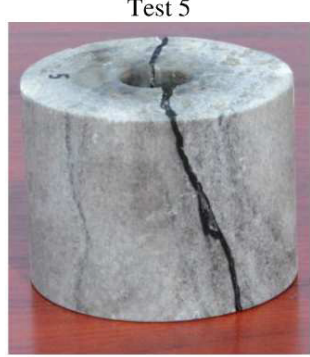

Test 6

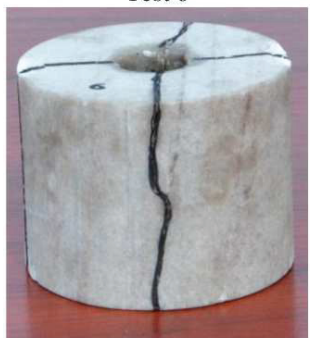

Test 7

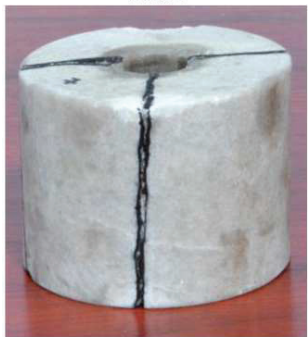

Test 8

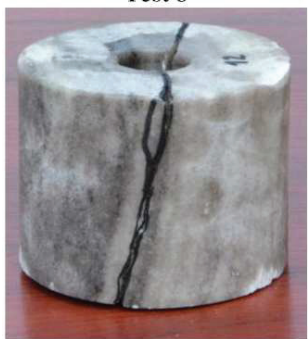

Slickwater

Test 9

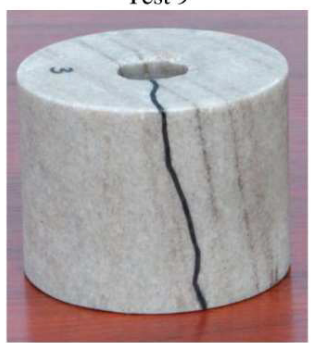

Test 10

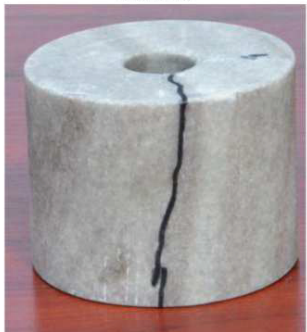

Test 11

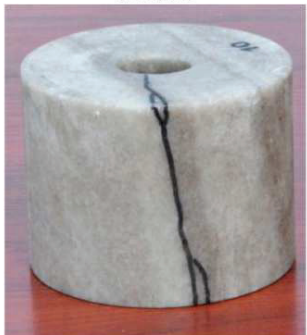

Test 12

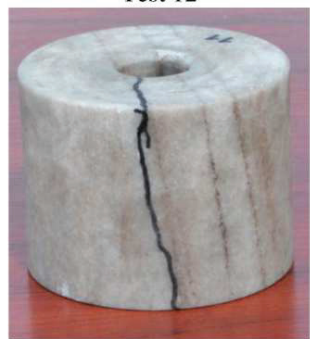

Fig. 2. Specimens after the test with fractures marked for better clarity

The obtained results summarized in Fig. 3 show that fracturing pressure depends significantly on fluid type. Repeatable results with a relative error within the range of 6-11\% show that both types of 
water-based fluids give similar results. A much lower $P_{c}$ value is obtained in the case of carbon dioxide.

Detailed observation of the samples after the experiment showed a similar damage pattern. Based on [10], the cylinder of material needs to withstand axial compressing and tensile hoop stress. In general, rocks (including marble) have a relatively low tensile strength. As a result, damage should be observed in the plane parallel to the axis of the specimen, and this is exactly what was noted in the experiments. The fracture surface either contains a sample axis of symmetry, or tilts towards it at a small angle.

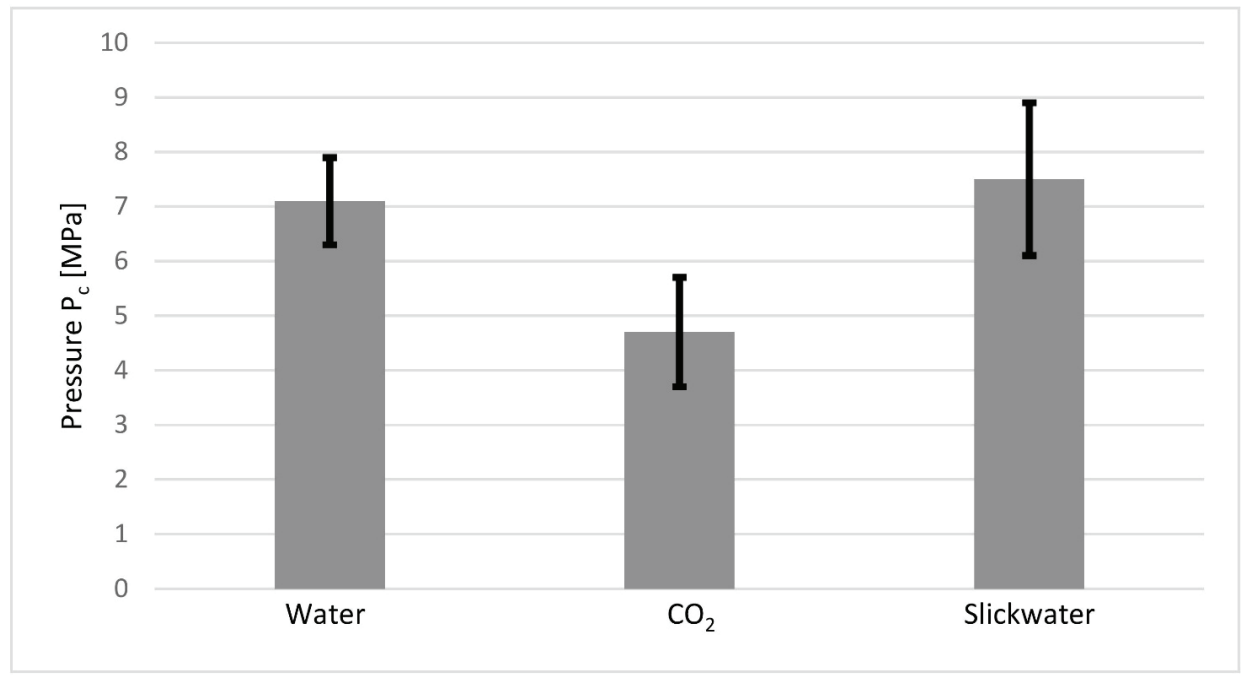

Fig. 3. Fracturing pressure and standard deviation for various fluids

\section{CONCLUSiOnS}

Investigations were carried out using a specifically designed stand for laboratory-based hydraulic fracturing. The main purpose of this work was the verification of the fracturing potential of various kinds of fluids. Repeatable results with a relative error in within the range of $6-11 \%$ prove that the experimental methodology was correct. Moreover, the obtained results show that fracturing pressure depends significantly on fluid type. In the case of the water test, the fracturing pressure was $7.1 \pm 0.4 \mathrm{MPa}$. A similar result was achieved for slickwater, $7.5 \pm 0.7 \mathrm{MPa}$; however, a much lower value $(4.7 \pm 0.5 \mathrm{MPa})$ was registered in the case of carbon dioxide. This behavior may be explained by microstructural behaviour; although rock material seems to be solid, it contains 
numerous pores filled with fluid [11]. Carbon dioxide has the ability to penetrate porous material and initiate a fracture more easily [5]. Unexpectedly, in the case of slickwater, the detected average pressure was higher than that registered for water. However, the physical properties of the fluids have not been verified and it remains unclear whether they have significantly lower viscosity. Moreover, the pressure is only slightly higher than for water and is within the range of measurement error. Furthermore, all the examined samples present a similar pattern of damage. The fracture surface tilts towards the sample axis at a small angle, meaning that hoop stress is responsible for material decohesion. Samples damaged with water or water with additives have only one fracture, while those on which carbon dioxide was utilized usually have two planes of fracture. This could be caused by the fact that liquid quickly loses its ability to load the sample; however, during decompression a gas still presses the surfaces of the initiated fractures, thereby causing their expansion.

\section{ACKNOWLEDGEMENTS}

The paper is supported by grant No BG2/DIOX4SHELL/14 titled "Development of guidelines for design of innovative technology of shale gas recovery with the use of liquid $\mathrm{CO}_{2}$ on the base of numerical and experimental research -DIOX4SHELL", supported by the National Centre for Research and Development (NCBR) in years 2014-2017. 


\section{REFERENCES}

1. N.R. Tschirhart, "The evaluation of waterfrac technology in low-permeability gas sands in the East Texas basin", Texas A\&M University, 2005.

2. M.K. Hubbert, D.G. Willis, "Mechanics of hydraulic fracturing. Transactions of American Institute of Mining Engineering" 210: 153-168, 1957.

3. L.O. Frash, "Laboratory-scale Study of Hydraulic Fracturing in Heterogeneous Media for Enhanced Geothermal Systems and General Well Stimulation”, Colorado School of Mines, 2014.

4. I. Matsunaga, H. Kobayashi, S. Sasaki, T. Ishida, „Studying hydraulic fracturing mechanism by laboratory experiments with acoustic emission monitoring”, Int. ,I. Rock Mech. Min. Sci., 30, 7, 909-912, 1993.

5. M.D. Zoback, "Reservoir Geomechanics", Cambridge University Press, USA, 2007.

6. B.C. Haimson, C. Fairhurst, "Initiation and extension of hydraulic fractures in rocks", Society of Petroleum Engineering Journal 7: 310-318, 1967.

7. P. Kędzierski, T. Niezgoda, G. Sławiński, "Development of Stand for Rock Material Fracturing in Laboratory Conditions", Sol. St. Phen., 94-97, 2015.

8. T. Ishida, K. Aoyagi, T. Niwa, Y. Chen, S. Murata, Q. Chen, Y. Nakayama, "Acoustic emission monitoring of hydraulic fracturing laboratory experiment with supercritical and liquid $\mathrm{CO}_{2}$ ", Geophys. Res. Lett., 39 (16), 2012

9. Y.Sun, "Impact of slickwater fracturing fluid compositions on the petrophysical properties of shale and tightsand", PHD thesis, Missouri University Of Science And Technology, 2014.

10. H. Xie, J. Pei, J. Zuo, R. Zhang, "Investigation of mechanical properties of fractured marbles by uniaxial compression tests", J. Rock Mech. Geotech. Eng., 3 (4), 302-313, 2011.

11. D. G. Prince, "Engineering Geology: Principles and Practice”, Springer-Verlag, United Kingdom, 2009. 


\section{LIST OF FIGURES AND TABLES:}

Fig. 1. Test stand

Rys. 1. Stanowisko badawcze

Fig. 2. Specimens after testing with fractures marked for better clarity

Rys. 2. Próbki po eksperymencie z zaznaczonymi pęknięciami dla lepszej prezentacji wyników

Fig. 3. Fracturing pressure and standard deviation for various fluids

Rys. 3. Ciśnienie szczelinowania i odchylenie standardowe dla różnych płynów

Tab. 1. Experimental results

Tab. 1. Wyniki eksperymentalne 


\section{SZCZELINOWANIE HYDRAULICZNE PRÓBEK SKALNYCH ZA POMOCĄ WODY, DITLENKU WĘGLA ORAZ „SLICKWATER"}

Słowa kluczowe: szczelinowanie hydrauliczne, stanowisko do szczelinowania, wytrzymałość skał na rozciąganie

\section{STRESZCZENIE:}

Szczelinowanie hydrauliczne polega na niszczeniu skały za pomocą płynu pod wysokim ciśnieniem w celu zwiększenia powierzchni spękań, co poprawia wydajność produkcyjna. Rozkład naprężenia w górotworach i jego wielkość jest zwykle relatywnie skomplikowana, a to utrudnia wykorzystanie informacji zgromadzonych w trakcie procesu szczelinowania w innej lokalizacji. Przy tym zwykle prace prowadzone są na dużym obszarze, a znaczna część instalacji znajduje się pod ziemią. W efekcie wiedza na temat warunków, w których przeprowadzono proces jest zwykle ograniczona. Dlatego próby laboratoryjne stanowią dobrą metodę weryfikacji parametrów procesu.

Jedną z najistotniejszych wielkości jest ciśnienie szczelinowania niezbędne do wytworzenia spękań. Decyduje ono zarówno o parametrach instalacji szczelinującej jak i ma wpływ na aktywność sejsmiczną obszaru. W literaturze istnieją wzory pozwalające szacować wielkość ciśnienia szczelinującego, jednak nie uwzględniają one roli płynu szczelinującego. Najpopularniejszym medium szczelinującym stosowanym w przemyśle jest woda, często domieszkowana specjalnymi dodatkami redukującymi tarcie. W górotworach o szczególnie zwartej budowie stosuje się zwykle ditlenek węgla lub azot. Dotychczasowe badania nad wpływem płynu szczelinującego na wielkość ciśnienia miały ograniczony charakter. Ze względu na ten fakt praca podejmuje to zagadnienie.

Próby szczelinowania hydraulicznego były wykonywane z użyciem specjalnie do tego skonstruowanego stanowiska badawczego. Stanowisko składało się z dwóch obwodów: a) niskiego, b) wysokiego ciśnienia. Układ wysokiego ciśnienia miał na celu podnosić ciśnienie płynu szczelinującego. Układ niskiego ciśnienia odpowiadał za wytwarzanie ciśnienia hydrostatycznego wokół próbki. Próbki wykonano z marmuru nie zawierającego żadnych widocznych pęknięć. W każdej z prób ciśnienie okalające wynosiło $4 \mathrm{MPa}$. Procedura badawcza polegała na stopniowym podnoszeniu ciśnienia w układzie wysokiego ciśnienia. Badano trzy rodzaje płynów: wodę, wodę z domieszkami (slickwater) oraz ditlenek węgla.

Uzyskane rezultaty pozwalają stwierdzić, że ciśnienie szczelinowania w znacznym stopniu zależy od rodzaju zastosowanego płynu. Powtarzalne rezultaty z błędem w zakresie 6-11\% pokazują, że szczelinowanie za pomocą wody $(7,1 \pm 0,4 \mathrm{MPa})$ oraz wody z domieszkami $(7,5 \pm 0,7 \mathrm{MPa})$ daje podobne wyniki. Natomiast zastosowanie ditlenku węgla pozwoliło na uzyskanie znacznie niższej wartości ciśnienia (4,7 $\pm 0,5 \mathrm{MPa})$. Tę różnicę można wyjaśniać biorąc pod uwagę budowę mikrostrukturalną marmuru. Ditlenek węgla ma zdolność penetrowania materiału skalnego, a przez to w łatwiej inicjuje pęknięcie. Zaobserwowano ponadto zbliżony sposób niszczenia próbek. W większości przypadków płaszczyzna pęknięcia była nachylona pod małym kątem do osi próbki, a to wskazuje, że za dekohezję materiału jest odpowiedzialne naprężenie obwodowe. 